\title{
Proposal to conserve the adjectival form of the specific epithet in the reclassification of Bacteroides forsythus Tanner et al. 1986 to the genus Tannerella Sakamoto et al. 2002 as Tannerella forsythia corrig., gen. nov., comb. nov. Request for an Opinion
}

Correspondence

M. F. J. Maiden

mmaiden@forsyth.org

\author{
M. F. J. Maiden, ${ }^{1}$ P. Cohee ${ }^{2}$ and A. C. R. Tanner ${ }^{1}$ \\ 'Department of Molecular Genetics, The Forsyth Institute, 140 Fenway, Boston, MA 02115, \\ USA \\ ${ }^{2}$ Department of Classics, Boston Latin School, Avenue Louis Pasteur, Boston, MA 02115, USA
}

\begin{abstract}
With reference to the first Principle of the International Code of Nomenclature of Bacteria, which emphasizes stability of names, it is proposed that the original adjectival form of the specific epithet be conserved in the reclassification of Bacteroides forsythus to the new genus Tannerella. Thus, Tannerella forsythensis Sakamoto et al. 2002 should be Tannerella forsythia Sakamoto et al. 2002 corrig., gen. nov., comb. nov., and we put forward a Request for an Opinion to the Judicial Commission regarding this correction.
\end{abstract}

A new genus, Tannerella, has recently been proposed (Sakamoto et al., 2002) for the oral anaerobe Bacteroides forsythus (Tanner et al., 1986), in accordance with previous genetic data (Paster et al., 1994). The original species name of the organism used the valid adjectival form forsythus, 'of Forsyth', referring to The Forsyth Institute, named for the founding Forsyth family, where the organism was first described. Although in this form the specific epithet included an orthographic error, this is readily corrected to Bacteroides forsythius corrig. (-ius being a clear adjectival form while $-u s$ is ambiguous). The only grammatical change required upon reclassification of the species to the new genus Tannerella (N.L. fem. n.) is therefore a change in gender agreement, thus N.L. fem. adj. forsythia. This minimal change is in accordance with the first Principle of the International Code of Nomenclature of Bacteria (The Code; Lapage et al., 1992), which aims at the stability of names to reduce the possibility of errors or confusion.

The specific epithet proposed for the new combination, forsythensis (Sakamoto et al., 2002), uses a different adjectival form from the original and this is a grammatically unnecessary change that may be confusing to researchers in the field. This form also constitutes a different epithet, thus the proposed combination is not in accordance with Rule 4la of The Code, which states that the specific epithet must be retained when a species is transferred from one

Published online ahead of print on 9 May 2003 as DOI 10.1099/ ijs.0.02641-0. genus to another. Further, the Latin ending -ensis/-ense is most appropriately used linguistically to indicate 'belonging to' or 'coming from' a geographical location in terms of a city, region or country, in the sense of inhabiting, or materially originating in, that place. This is the context in which the ending is applied for most bacterial species names that use it. In historical Latin usage, an institution or building would be considered too limited a location to warrant the -ensis ending, plus an institution is rarely inhabited (infected) by the organisms that may be described there. This is especially so with human commensal or pathogenic species that are isolated from subjects of diverse geographical origins who merely visit the institution to be sampled. For these reasons, an epithet in the simple adjectival form is more appropriate to associate a species with an institution.

From the reasons described above, we herein propose that, in the reclassification of Bacteroides forsythus Tanner et al. 1986 to the genus Tannerella Sakamoto et al. 2002, the original adjectival form of the specific epithet be conserved in the combination Tannerella forsythia corrig., gen. nov., comb. nov., and we put forward a Request for an Opinion to the Judicial Commission regarding this point.

\section{References}

Lapage, S. P., Sneath, P. H. A., Lessel, E. F., Skerman, V. B. D., Seeliger, H. P. R. \& Clark, W. A. (editors) (1992). International Code of Nomenclature of Bacteria (1990 Revision). Bacteriological Code. Washington, DC: American Society for Microbiology. 
Paster, B. J., Dewhirst, F. E., Olsen, I. \& Fraser, G. J. (1994). Phylogeny of Bacteroides, Prevotella, and Porphyromonas spp. and related bacteria. J Bacteriol 176, 725-732.

Sakamoto, M., Suzuki, M., Umeda, M., Ishikawa, I. \& Benno, Y. (2002). Reclassification of Bacteroides forsythus (Tanner et al. 1986) as Tannerella forsythensis corrig., gen. nov., comb. nov. Int J Syst Evol Microbiol 52, 841-849.

Tanner, A. C. R., Listgarten, M. A., Ebersole, J. L. \& Strzempko, M. N. (1986). Bacteroides forsythus sp. nov., a slow-growing, fusiform Bacteroides sp. from the human oral cavity. Int J Syst Bacteriol 36, 213-221. 